\section{Rapid Preparation of Thermus flavus DNA Polymerase}

\author{
Robert A. Harrell II and \\ Ronald P. Hart
}

Department of Biological Sciences, Rutgers University, Newark, New Jersey

07102
PCR depends on the use of a thermostable DNA polymerase. ${ }^{(1,2)}$ Several thermostable DNA polymerases are commercially available from a number of thermophilic bacterial cells, including Thermus aquaticus, Thermus flavus, and members of the Pyrococcus family. Other polymerases have been purified from Thermus thermophilus ${ }^{(3,4)}$ and Thermus caldophilus. ${ }^{(5)}$ The polymerase that we found to be most suitable for our needs ${ }^{(6,7)}$ was isolated from the thermophilic bacteria T. flavus (e.g., HotTub, Amersham, or Pyrostase, Molecular Genetics Resources). A T. flavus DNA polymerase has been isolated and characterized previously. ${ }^{(8,9)}$ Unfortunately, the published procedure for DNA polymerase isolation was laborious and inefficient. Therefore, we developed a rapid preparation method suited to our needs. A flow diagram outlining our procedure is given in Figure 1.

\section{MATERIALS AND METHODS}

\section{Bacterial Culture}

T. flavus was obtained from American Type Culture Collection (ATCC 33923; also known as $T$. aquaticus type AT62) and grown from a $50-\mathrm{ml}$ seed culture in a 5-liter Bioflo II Fermenter (New Brunswick Scientific, Inc.) at $65-70^{\circ} \mathrm{C}$ on synthetic medium containing $2 \%$ (wt/vol) peptone, $0.2 \%$ (wt/vol) yeast extract, $0.1 \%$ (wt/vol) beef extract, $50 \mathrm{~mm}$ Tris-
$\mathrm{HCl}$ (pH 8.0), 0.25\% (vol/vol) sodium lactate, $4.2 \mathrm{~mm}$ succinic acid, $5.9 \mathrm{~mm}$ glutamic acid, $3.8 \mathrm{~mm} \mathrm{~K}_{2} \mathrm{HPO}_{4}, 0.48 \mathrm{~mm}$ $\mathrm{MgSO}_{4}, 0.38 \mathrm{~mm} \mathrm{CaCl}$, and $8.5 \mathrm{~mm}$ $\mathrm{NaCl} .^{\left({ }^{8}\right)}$ The fermenter vessel and its heating lines were wrapped in aluminum foil to keep the temperature near $70^{\circ} \mathrm{C}$.

Growth was monitored by $A_{650}$ and allowed to continue until stationary phase ( $\sim 24 \mathrm{hr}$ postinoculation). Once stationary phase was reached, the culture was pumped into 0.5 -liter centrifuge bottles and the cells collected by centrifugation at $4000 \mathrm{rpm}$ using a JS-42 rotor in a J6-B centrifuge (Beckman). The pellets were resuspended in buffer $\mathrm{A}(0.14 \mathrm{M}$ $\mathrm{NaCl}$ and $0.01 \mathrm{M}$ Tris- $\mathrm{HCl} \mathrm{pH}$ at 8.0) and consolidated. Approximately 30 grams of cells were obtained from this 5-liter culture. The cell pellet was stored frozen at $-80^{\circ} \mathrm{C}$.

\section{Enzyme Assay}

During isolation of DNA polymerase, activity was assessed by a primer extension assay. Activity was determined by incorporation of $\left[\alpha^{32} \mathrm{P}\right] \mathrm{dATP}$ into high-molecular-weight DNA on a primed singlestranded M13 phage DNA template. Enzyme fractions were assayed by addition of $680 \mathrm{ng}$ of single-stranded M13mp19 DNA and $5 \times 10^{-4}$ ng of 17 mer M13 universal primer (U.S. Biochemical) in a 5 - $\mu$ l reaction containing 1 


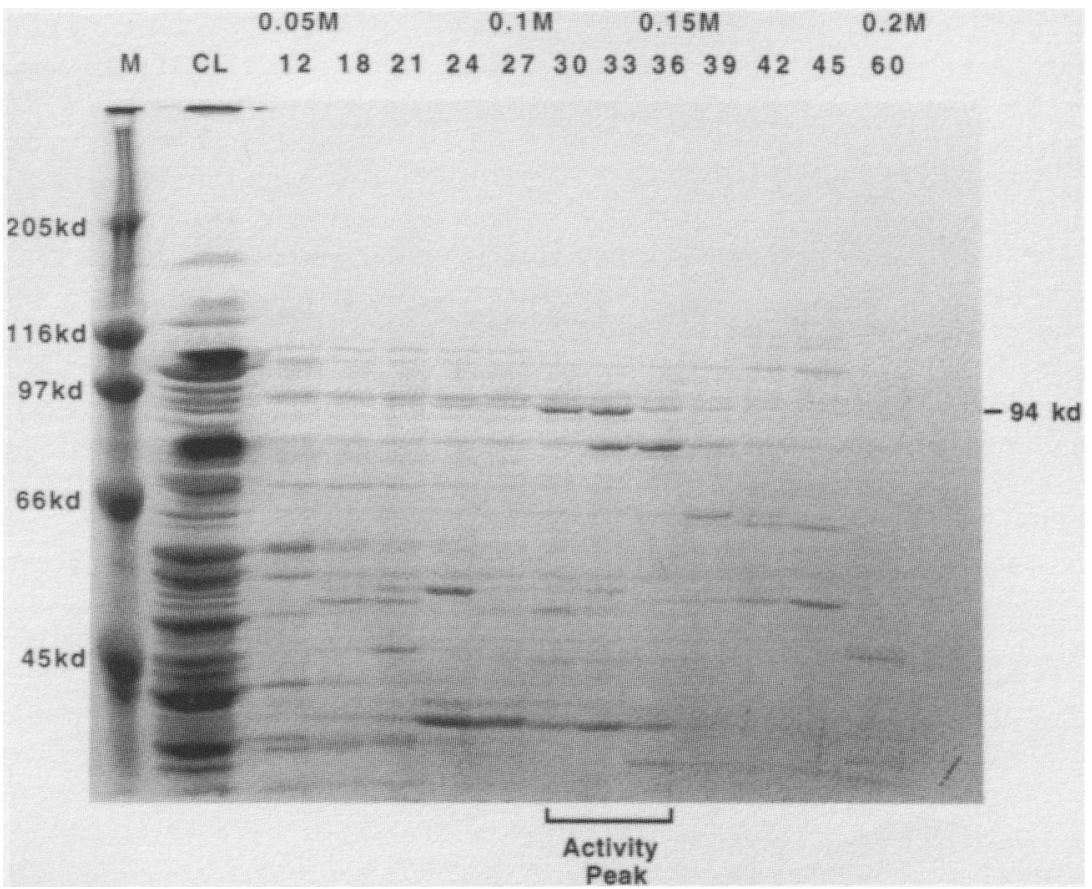

FIGURE 2 Ten percent SDS-PAGE of S-Sepharose column fractions. Fraction numbers are shown at the top of each lane. Conductivity testing indicated the $\mathrm{KCl}$ concentrations shown. Fractions 30-36 exhibited maximal levels of DNA polymerase activity (see Figs. 3 and 4). (Right) The 94-kD band that best correlates with enzyme activity levels and further protein purification (Fig. 5). (M) Marker: $20 \mathrm{kD}$ rabbit muscle myosin, $116 \mathrm{kD}$ E. coli $\beta$-galactosidase, $97 \mathrm{kD}$ rabbit muscle phosphorylase, $66 \mathrm{kD}$ bovine albumin, and $45 \mathrm{kD}$ ovalbumin. (CL) Column load.

$\mu \mathrm{l}$ of enzyme fraction, 50 mм HEPES, 1.5 $\mathrm{mM} \mathrm{MgCl}, 50 \mathrm{~mm} \mathrm{KCl}, 100 \mu \mathrm{M}$ each of dGTP, dTTP, and dCTP, and $10 \mu \mathrm{M}$ dATP including $1 \mu \mathrm{Ci}$ of $\left[\alpha^{-32} \mathrm{P}\right] \mathrm{dATP}$ (DuPont NEN). The reactions were incubated for $1 \mathrm{~min}$ at $37^{\circ} \mathrm{C}$, then for $3 \mathrm{~min}$ at $65^{\circ} \mathrm{C}$. The reactions were stopped by addition of $10 \mu \mathrm{l}$ of deionized formamide containing $0.1 \%$ (wt/vol) xylene cyanol. Samples were heat denatured, run on a $6 \%$ polyacrylamide sequencing gel, and visualized by autoradiography. The activity of sample was judged by comparing the amount and size of product with standard reactions performed with commercial enzymes. ${ }^{(10)}$

\section{PCR Conditions}

$T$. flavus DNA polymerase was also tested for activity in PCR. The target DNA was a cloned PCR product of rat vasoactive intestinal peptide cDNA prepared previously in our laboratory by cloning reverse transcriptase (RT)-PCR products. Reactions were performed in a volume of $50 \mu \mathrm{l}$ containing $50 \mathrm{~mm}$ Tris ( $\mathrm{pH} \mathrm{9.0),} 20$ $\mathrm{mM}\left(\mathrm{NH}_{4}\right)_{2} \mathrm{SO}_{4}, 1.5 \mathrm{mM} \mathrm{MgCl}_{2}, 0.005 \%$ BSA, $0.2 \mathrm{~mm}$ each of dATP, dGTP, dTTP, and dCTP, $1 \mu \mathrm{M}$ of each primer, and 50 pg of pBSVIP template DNA (C. Liu and R.P. Hart, unpubl.). The primers were VIP472 (5'-AGGAAGTCTGGAGAATCTCCCTCA-3') and VIP228 (5'-GGAGTTTTCACCAGCGACTACAGT-3'), designed from rat VIP $c D N A$ sequence. ${ }^{(11)}$ The reactions were amplified for 30 cycles of $94^{\circ} \mathrm{C}$ for $30 \mathrm{sec}, 60^{\circ} \mathrm{C}$ for $30 \mathrm{sec}$, and $72^{\circ} \mathrm{C}$ for $3 \mathrm{~min}$, followed by an 8-min extension period at $72^{\circ} \mathrm{C}$. The products were precipitated and electrophoresed on a $1 \%$ agarose gel. DNA polymerase activity was judged by the presence and relative intensity of specific PCR product (predicted to be $245 \mathrm{bp}$ ). In general, the PCR assay was more useful for identifying fractions containing activity, but the primer extension assay was better at judging relative enzyme activity.

\section{Temperature Stability}

The temperature stability of three DNA polymerase preparations was compared by pretreating complete PCR reactions at $94^{\circ} \mathrm{C}$, then proceeding with a standard PCR reaction. Each reaction mixture contained $\sim 0.2$ unit (chosen to be sub- saturating for enzyme; 1 unit is the amount of enzyme that will incorporate 10 nmoles of dNTP into acid insoluble product at $70^{\circ} \mathrm{C}$ in $30 \mathrm{~min}$ ) of enzyme or no added enzyme. Units of $T$. flavus DNA polymerase were determined by comparing enzyme reactivity in a primer extension assay with dilutions of Pyrostase (data not shown). Units of Pyrostase and Taq polymerase were determined by their manufacturer.

\section{RESULTS}

\section{Isolation of DNA Polymerase}

$T$. flavus DNA polymerase was partially purified by a combination of polycation precipitation and column chromatography. Frozen cell pellets were thawed by

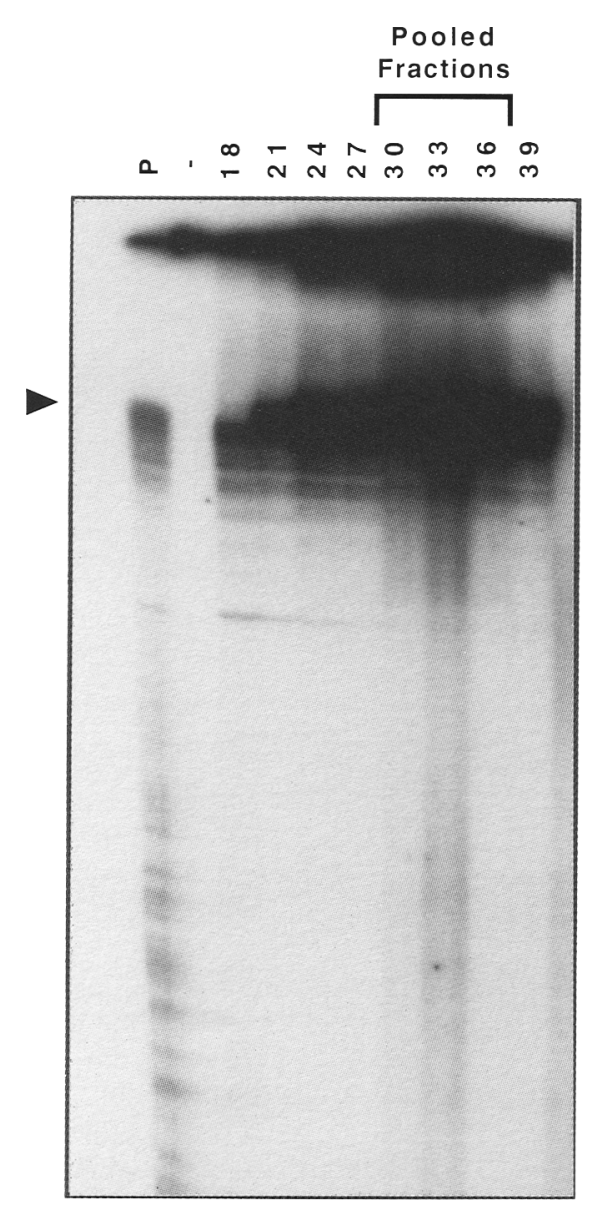

FIGURE 3 Primer extension assay of S-Sepharose column fractions. DNA polymerase activity was detected by extending primed M13 DNA with radiolabeled nucleotide triphosphate. Products were revealed by autoradiography of dried sequencing gels. Bands at arrowhead indicate polymerase activity. (P) Pyrostase; ( - ) no added enzyme. 


\section{Technical TipsIIIIII}

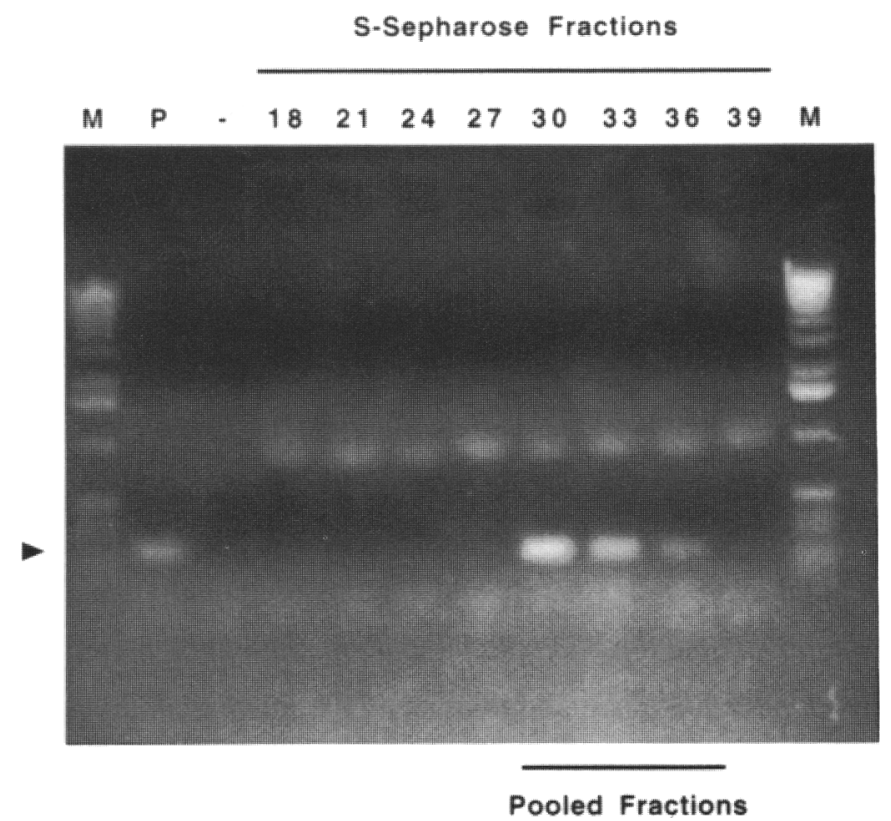

FIGURE 4 PCR assay of S-Sepharose column fractions. DNA polymerase activity was detected by 30 cycles of PCR using $50 \mathrm{pg}$ of pBSVIP plasmid DNA and two VIP-specific primers. Products were separated on $1 \%$ agarose gels, stained with ethidium bromide, and photographed under UV illumination. (Arrowhead) Position of predicted VIP cDNA product band. (M) One-kilobase ladder (GIBCO BRL); (P) Pyrostase; ( - ) no added enzyme.

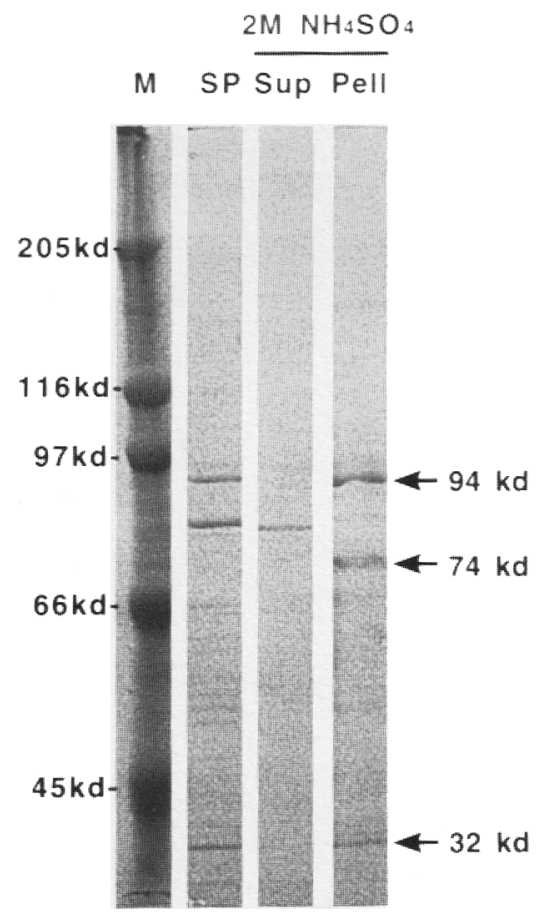

FIGURE 5 Ten percent SDS-PAGE of $2 \mathrm{M}$ ammonium sulfate precipitation. Pooled, peak activity S-Sepharose column fractions (SP) were precipitated by adding ammonium sulfate to a final concentration of $2 \mathrm{M}$. A sample of the supernatant $(S)$ and the pellet $(\mathrm{P})$ were loaded onto a $10 \%$ SDS-PAGE, electrophoresed, and visualized by Coomassie staining. Lanes shown are selected from a single gel. (M) Marker (see Fig. 2). addition of 2 volumes of cold buffer B [10 $\mathrm{mm}$ Tris- $\mathrm{HCl}(\mathrm{pH} 7.9), 50 \mathrm{~mm} \mathrm{KCl}, 1$ mM EDTA, $0.5 \mathrm{~mm}$ phenylmethylsulfonyl fluoride (PMSF), $0.5 \%$ (vol/vol) Tween 20, 0.5\% (vol/vol) Nonidet-P40 (NP-40)] and then broken apart with a spatula. The resuspended cells were subjected to 20 rounds of sonication [1 (GIBCO BRL). round $=10 \mathrm{sec}$ of sonication at $20 \mathrm{kHz}$ with $50 \mathrm{sec}$ of rest, W-385 Sonicator (Heat Systems-Ultrasonics INC.)], and light scattering at $650 \mathrm{~nm}$ was measured. Sonication was continued with an $A_{650}$ measurement after every fifth round until the $A_{650}$ stabilized. The solution was then centrifuged for $30 \mathrm{~min}$ at $22,100 \mathrm{~g}$. The supernatant was clarified by centrifugation for $1 \mathrm{hr}$ at $80,000 \mathrm{~g}$.

Then, polyethyleneimine (PEI) was used to precipitate the DNA polymerase following a method used for isolation of overexpressed Taq polymerase. ${ }^{(10)}$ Engelke et al. found that the concentration of PEI used to precipitate Taq polymerase varied between preparations. ${ }^{(10)}$ Therefore, a PEI precipitation test was done for each preparation. Concentrations between $0.05 \%$ and $0.8 \%(\mathrm{wt} / \mathrm{vol})$ PEI were tested to determine the appropriate concentration to precipitate enzyme activity. Once the proper concentration for precipitation was determined, the remainder of the high-speed supernatant was brought to this concentration by dropwise addition of $10 \%$ (wt/ vol) PEI. This mixture was incubated for $10 \mathrm{~min}$ at room temperature and centrifuged for $20 \mathrm{~min}$ at $8000 \mathrm{~g}$.

The pellet was washed by resuspending in a glass Dounce with $0.025 \mathrm{M} \mathrm{KCl}$ in buffer $\mathrm{C}$ [20 mM HEPES at $\mathrm{pH} 7.9,1 \mathrm{~mm}$ EDTA, $0.5 \mathrm{~mm}$ PMSF, $0.5 \%$ (vol/vol) Tween 20 , and $0.5 \%$ (vol/vol) NP40]. The resuspended pellet was centrifuged for

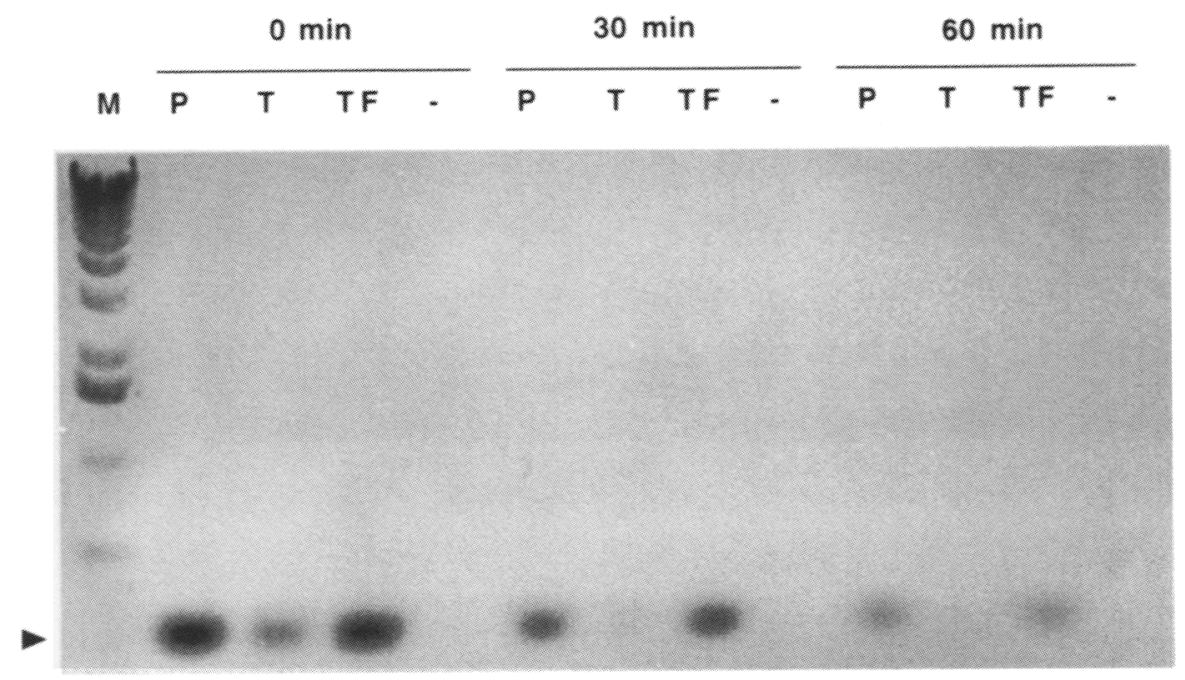

FIGURE 6 Temperature stability assay. PCR reactions were assembled with DNA polymerase from $T$. flavus (TF), Pyrostase (P), Taq Polymerase (T), or no added enzyme $(-)$. The reactions were held at $94^{\circ} \mathrm{C}$ for the times indicated and amplified for 30 cycles as usual. PCR product was run on a $1 \%$ agarose gel, stained, and photographed under UV illumination. (M) One-kilobase ladder 


\section{DIIIII Technical Tips}

$10 \mathrm{~min}$ at $8000 \mathrm{~g}$. The enzyme was then eluted from this pellet by resuspending in $0.15 \mathrm{M} \mathrm{KCl}$ in buffer $\mathrm{C}$ and centrifuging for $10 \mathrm{~min}$ at $8000 \mathrm{~g}$ to remove debris. This supernatant was diluted to $50 \mathrm{~mm}$ $\mathrm{KCl}$ by addition of buffer $\mathrm{C}$.

The diluted sample was loaded onto a $40 \mathrm{ml}$ equilibrated S-Sepharose column (Pharmacia, Piscataway, NJ). The column was washed back to baseline $A_{280}$ with buffer $\mathrm{C}$ and eluted with a linear $0-0.3 \mathrm{M} \mathrm{KCl}$ gradient. Selected fractions were run on a $10 \%$ SDS-polyacrylamide gel (Fig. 2).

S-Sepharose column fractions were then assayed for activity by both the primer extention (Fig. 3) and PCR assays (Fig. 4). The primer extension assay shows polymerase activity across a broad range of fractions, but the PCR assay shows that the major portion of activity is between fractions 30 and 36 . The active fractions and the relative activity in each fraction best corresponds to a band of $\sim 94 \mathrm{kD}$ in Figure 2. This hypothesis correlates well with the results of ammonium sulfate precipitation (Fig. 5).

The fractions with peak activity (fractions 30-36) were pooled and subjected to precipitation by addition of ammonium sulfate to a final concentration of 2 M. Activity was found to be associated with the pellet of this precipitation. The pellet, resuspended in $1 \mathrm{ml}$ of buffer $\mathrm{C}$, is stored at $4^{\circ} \mathrm{C}$ and has not lost activity during 5 months of storage (not shown).

A $10 \%$ SDS-PAGE analysis of the $2 \mathrm{M}$ ammonium sulfate supernatant and pellet is shown in Figure 5. The resuspended pellet contains only three major bands of approximate $M_{\mathrm{r}} 94,000,74,000$, and 32,000 daltons. The $74-\mathrm{kD}$ band was not observed in the S-Sepharose column pool and may, therefore, be a breakdown product of the $94-\mathrm{kD}$ protein. The smallest protein, $\sim 32 \mathrm{kD}$, was observed in the S-Sepharose column fractions with no PCR activity (fractions 24-27; see Fig. 2). We conclude that the active DNA polymerase protein is most likely the $94-\mathrm{kD}$ band.

\section{Test of Polymerase Thermostability}

The thermostability of isolated $T$. flavus DNA polymerase in a reaction mixture was compared with the commercial enzymes Taq polymerase (Promega, Madison, WI) and Pyrostase (Molecular Genetic Resources, Tampa, FL) by a PCR assay. Reaction mixtures (see Materials and Methods) containing one of the three enzymes or no added enzyme were incubated at $94^{\circ} \mathrm{C}$ for 0,30 , or $60 \mathrm{~min}$ followed by a standard PCR reaction. While other reaction components besides the polymerase enzyme decay during the $94^{\circ} \mathrm{C}$ treatment, we found that heat treatment of the enzyme alone completely inactivated all enzymes tested (not shown). The $T$. flavus DNA polymerase and Pyrostase both retained activity past $60 \mathrm{~min}$, whereas the Taq polymerase lost activity after $30 \mathrm{~min}$ (Fig. 6).

\section{DISCUSSION}

We have prepared a strongly enriched fraction of $T$. flavus DNA polymerase. The precise fold enrichment could not be measured here because of the lack of detectable polymerase activity in crude extract. However, gel electrophoresis detects only three major bands, and we conclude that the activity best correlates with a 94-kD band (see Figs. 2 and 5), which is the same relative mass determined for Taq polymerase ${ }^{(10)}$ and $T$. caldophilus. ${ }^{(5)}$ This is in contrast to the work of Kaledin et al., ${ }^{(8)}$ who claim to have isolated a $66-\mathrm{kD}$ DNA polymerase from $T$. flavus. However, DNA sequence data from workers at the Russian Academy of Sciences for a $T$. flavus DNA polymerase clone ${ }^{(9)}$ do not hybridize well with DNA that we have isolated from our ATCC 33923 isolate (Y. Bai and R.P. Hart, unpubl.). Therefore, it is possible that we are studying different varieties of Thermus. We are presently preparing the DNA polymerase gene from ATCC 33923 for overexpression in Escherichia coli.

Our method allows relatively quick isolation of PCR- and sequencing-quality thermostable DNA polymerase. In 5 days one can isolate $\sim 8000$ units of enzyme, enough to do nearly $16,00050-\mu l$ PCR reactions, at a minimal cost in time and materials. This method is ideal for laboratories that utilize large quantities of thermostable DNA polymerase.

\section{ACKNOWLEDGMENTS}

This work was supported by the National Institutes of Health $\mathrm{MH} 00855$ and NS 30560) and the Charles and Johanna Busch Memorial Fund of Rutgers University. We thank Changlu Liu for providing pBSVIP DNA.

\section{REFERENCES}

1. Mullis, K., F. Faloona, S. Scharf, R. Saiki, G. Horn, and H. Erlich. 1986. Specific enzymatic amplification of DNA in vitro: The polymerase chain reaction. Cold Spring Harbor Symp. Quant. Biol. 51: 263-273.

2 Mullis, K.B. and F.A. Faloona. 1987. Specific synthesis of DNA in vitro via a polymerase-catalyzed chain reaction. Methods Enzymol. 155: 335-350.

3. Carballeira, N., M. Nazabal, J. Brito, and O. Garcia. 1990. Purification of a thermostable DNA polymerase from Thermus thermophilus HB8, useful in the polymerase chain reaction. BioTechniques 9: 276-281.

4. Myers, T.W. and D.H. Gelfand. 1991. Reverse transcription and DNA amplification by a Thermus thermophilus DNA polymerase. Biochemistry 30: 7661-7666.

5. Park, J.H., J.S. Kim, S.T. Kwon, and D.S. Lee. 1993. Purification and characterization of Thermus caldophilus GK24 DNA polymerase. Eur. J. Biochem. 214: 135140.

6. Shadiack, A.M., R.P. Hart, C.D. Carlson, and G.M. Jonakait. 1993. Interleukin-1 induces substance $P$ in sympathetic ganglia through the induction of leukemia inhibitory factor (LIF). J. Neurosci. 13: 26012609.

7. Hart, R.P., C. Liu, A.M. Shadiack, R.J. McCormack, and G.M. Jonakait. 1993. An mRNA homologous to interleukin-1 receptor type $\mathrm{I}$ is expressed in cultured rat sympathetic ganglia. J. Neuroimmunol. 44: 49-56.

8. Kaledin, A.S., A.G. Slyusarenko, and S.I. Gorodetskii. 1981. Isolation and properties of DNA polymerase from the extremely thermophilic bacterium Thermus flavus. Biokhimiya 46: 1576-1584.

9. Akhmetzjanov, A.A. and V.A. Vakhitov. 1992. Molecular cloning and nucleotide sequence of the DNA polymerase gene from Thermus flavus. Nucleic Acids Res. 20: 5839 .

10. Engelke, D.R., A. Krikos, M.E. Brock, and D. Ginsburg. 1990. Purification of Thermus aquaticus DNA polymerase expressed in Escherichia coli. Anal. Biochem. 191: $396-400$.

11. Nishizawa, M., Y. Hayakawa, N. Yanaihara, and H. Okamoto. 1985. Nucleotide sequence divergence and functional constraint in VIP precursor mRNA evolution between human and rat. FEBS Lett. 183: 55-59.

Received February 24, 1994; accepted in revised form March 30, 1994. 


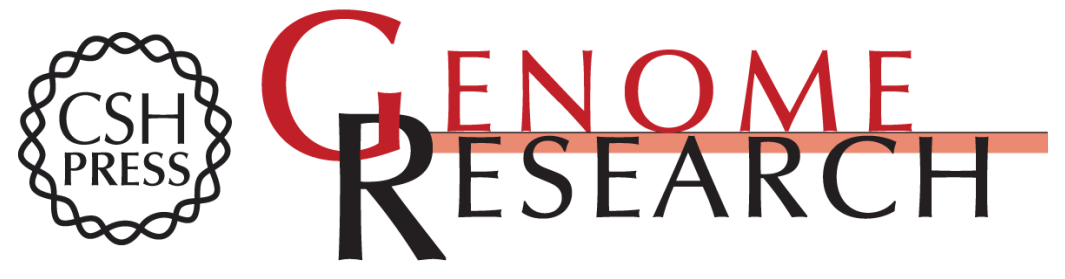

\title{
Rapid preparation of Thermus flavus DNA polymerase.
}

\author{
R A Harrell and R P Hart
}

Genome Res. 1994 3: 372-375

References This article cites 11 articles, 2 of which can be accessed free at:

http://genome.cshlp.org/content/3/6/372.full.html\#ref-list-1

\section{License}

Email Alerting Receive free email alerts when new articles cite this article - sign up in the box at the Service top right corner of the article or click here.

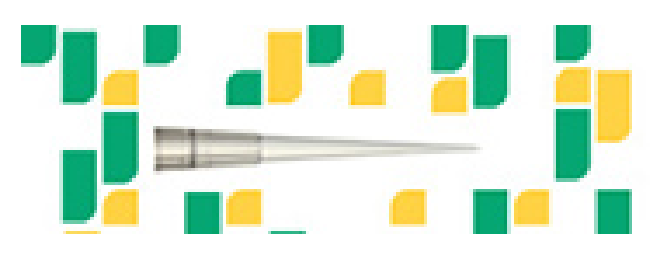

To subscribe to Genome Research go to: https://genome.cshlp.org/subscriptions 